\title{
Kesalahan Berbahasa Penulisan Tugas Mahasiswa Pembelajaran Online Learning Masa Pandemi Covid-19
}

\author{
Silvia Ratna Juwita ${ }^{1}$, Nia Puspita Hapsari ${ }^{2}$ \\ ${ }^{1,2}$ Universitas Esa Unggul \\ e-mail: ${ }^{1}$ silvia.ratna@esaunggul.ac.id; ${ }^{2}$ niapeha@esaunggul.ac.id

\begin{tabular}{ccc}
\hline Diterima & Direvisi & Disetujui \\
$23-02-2021$ & $20-03-2021$ & $25-03-2021$ \\
\hline
\end{tabular}

\begin{abstract}
This study aims to describe and assess language errors in the writing of university course assignments (MKU) for students of Esa Unggul University online learning during the Covid-19 pandemic. The work process of qualitative research with the content analysis method is used in this study. The data of this research are student assignments in three university courses: Indonesian, Citizenship Education, and Islam. Sources of data in this study are student assignments on online learning in the 2020 odd semester of the Covid-19 pandemic. The findings of this study were (1) errors in writing conjunctions, (2) errors in writing capital letters, (3) errors in using punctuation marks, and (4) errors in writing standard words. The purpose of this research is not only to add insight to the general public but also to consider teaching materials for tertiary institutions and secondary schools.
\end{abstract}

Keywords: online learning, covid-19, language, lecture

\begin{abstract}
Abstrak - Penelitian ini bertujuan untuk mendeskripsikan dan mengaji kesalahan berbahasa pada penulisan tugas mata kuliah universitas (MKU) mahasiswa pembelajaran online learning Universitas Esa Unggul masa pandemi Covid-19. Proses kerja penelitian kualitatif dengan metode analisis isi digunakan dalam penelitian ini. Data penelitian ini adalah tugas mahasiswa pada tiga mata kuliah univeritas: Bahasa Indonesia, Pendidikan Kewarganegaraan, dan Agama Islam. Sumber data dalam penelitian ini adalah tugas mahasiswa pada online learning semester ganjil 2020 masa pandemi Covid-19. Temuan penelitian ini berupa (1) kesalahan penulisan konjungsi, (2) kesalahan penulisan huruf kapital, (3) kesalahan penggunaan tanda baca, dan (4) kesalahan penulisan kata baku. Kegunaan dari penelitian ini selain untuk menambah wawasan bagi khalayak umum juga sebagai pertimbangan materi ajar bagi perguruan tinggi dan menengah.
\end{abstract}

Kata Kunci: pembelajaran daring, covid-19, bahasa, mahasiswa

\section{PENDAHULUAN}

Dunia pendidikan, lembaga pendidikan, khususnya perguruan tinggi, sedang mengalami tantangan yang cukup berat imbas dari wabah corona virus disease 2019 yang melanda 215 negara ini. Adanya pembatasan sosial (social distancing) yang di antaranya terdapat larangan pemerintah untuk berkerumun, menjaga jarak secara fisik, memakai masker, mencuci tangan menjadi kendala tersendiri bagi lembaga pendidikan untuk melaksanakan kegiatan pembelajaran tatap muka seperti biasanya sehingga mengacu pada Surat Edaran Kemendikbud Dikti No.1 tahun 2020, perguruan tinggi diminta untuk tetap menyelenggarakan pembelajaran daring atau online selama wabah Covid-19 melanda. (Sadikin \& Hamidah, 2020)
Dabbagh dan Ritland mengemukakan pembelajaran online merupakan sistem pembelajaran yang terbuka dan tersebar dengan menggunakan perangkat pedagogi (alat bantu pendidikan), yang dimungkinkan melalui internet dan teknologi berbasis jaringan untuk memfasilitasi pembentukan proses belajar dan pengetahuan melalui aksi dan interaksi yang berarti. (Arnesti \& Hamid, 2015)

Universitas Esa Unggul telah menerapkan pembelajaran sistem hybrid atau yang disebut dengan online learning. Sistem pembelajaran online learning dilakukan dengan full online, yaitu 14 sesi perkuliahan dilaksanakan dengan metode online menggunakan e-learning (asynchronous) dan 3 pertemuan pengayaan, tatap muka yang tidak bersifat wajib atau opsional untuk dihadiri oleh 
peserta belajar, tetapi wajib dihadiri oleh dosen pengampu mata kuliah yang bersifat hybrid, di antaranya yang telah melaksanakan pembelajaran secara daring tersebut adalah mata kuliah universitas: Bahasa Indonesia, Pendidikan Kewarganegaraan, dan Agama Islam. Namun, dengan adanya wabah pandemi Covid-19 ini, pembelajaran baik untuk kelas regular ataupun karyawan dan seluruh mata kuliah menggunakan e-learning dan tiga pertemuan pengayaan (konvensional) diganti dengan menggunakan pembelajaran synchronous Google Meet atau Zoom Meeting.

Beberapa istilah digunakan dalam mengemukakan pendapat/gagasan tentang pembelajaran elektronik: online learning, internet-enabled learning, virtual learning, atau web-based learning. E-learning itu sendiri merupakan teknologi informasi dan komunikasi yang digunakan untuk mengaktifkan siswa dalam belajar kapan pun dan di mana pun. Ada tiga hal yang harus diperhatikan sebagai syarat kegiatan belajar elektronik: (1) kegiatan pembelajaran dilakukan melalui pemanfaatan jaringan (internet); (2) tersedianya dukungan layanan belajar yang dimanfaatkan dalam pembelajaran seperti External Harddisk, Flashdisk, CDRoom, atau bahan cetak; (3) tersedianya dukungan layanan tutor yang dapat membantu peserta belajar bila mengalami kesulitan. (Hartanto, 2016)

Online Learning dianggap memberikan solusi pada kegiatan belajar mengajar khususnya kelas karyawan (paralel) dimana metode hybrid dinilai efisien mengurangi tingkat ketidaklulusan mahasiswa yang dikarenakan absensi. Untuk kelas paralel yang didominasi mahasiswa pekerja, absensi dianggap menjadi hal tersulit karena ada kemungkinan mahasiswa tidak dapat menghadiri perkuliahan tatap muka dengan berbagai alasan, salah satunya pekerjaan (masih berada dalam kegiatan bekerja, jarak dan waktu tempuh yang tidak mencukupi untuk hadir sehingga terlambat), sedangkan mahasiswa harus mencapai target minimal 75\% kehadiran untuk dapat mengikuti Ujian Akhir Semester (UAS). Dan apabila mahasiswa tidak dapat mencapai persentase absensi berikut maka mahasiswa tersebut tidak dapat mengikuti UAS shingga mengakibatkan ketidaklulusan mahasiswa secara otomatis.
Di balik efisensi belajar dengan metode hybrid tersebut, dalam pembelajaran online mahasiswa dituntut berperan lebih aktif. Hal ini dikarenakan sistem belajar online adalah satu arah (tidak realtime) sehingga mahasiswa adalah peran utama untuk mencari solusi dalam menyelesaikan kewajibannya yaitu mengerjakan tugas dan kuis. Pembelajaran yang dilaksanakan dengan tatap muka memberi kesempatan mahasiswa untuk bertanya langsung kepada dosen bila ada masalah dalam pembelajaran yang kurang/tidak dipahami oleh mahasiswa sebagai peserta belajar.

Tentunya pembelajaran online yang masih dalam penyesuaian bagi yang terlibat baik dosen maupun mahasiswa itu sendiri, masih terdapat beberapa hal yang belum leluasa dilaksanakan, seperti kesulitankesulitan belajar atau ketidakpahaman materi yang tidak bisa secara langsung (konvensional) dijelaskan secara rinci. Salah satu ketidakpahaman yang menyebabkan kesalahan yang akan dibahas dalam penelitian kali ini adalah adanya kesalahan berbahasa yang digunakan oleh mahasiswa pada tugas-tugas yang dikumpulkan.

Kesalahan berbahasa merupakan penggunaan bahasa yang menyimpang dari faktor-faktor tertentu berkomunikasi baik secara lisan maupun tulisan; menyimpang dari norma kemasyarakatan dan menyimpang dari kaidah tata bahasa Indonesia. Aturan penulisan itu sendiri sudah diatur dengan jelas dalam bahasa Indonesia yakni di antaranya pada buku Pedoman Umum Ejaan Bahasa Indonesia (PUEBI), buku penyuluhan kalimat, buku penyuluhan paragraf, serta banyak buku teori yang menjelaskan perihal syarat atau aturan penulisan ejaan, diksi, kalimat, dan paragraf dari badan bahasa.(Netty Fitria Dinanti, Susetyo, 2019)

Kesalahan berbahasa yang dilakukan oleh pemakai bahasa dapat terjadi karena pengguna bahasa tidak memahami kaidah kebahasaan yang baik dan benar juga tidak berhati-hati dalam menggunakan bahasa. Kesalahan itulah yang dijadikan sebagai bidang kajian analisis kesalahan berbahasa yang memiliki hubungan erat dengan linguistik. Kesalahan berbahasa dalam proses pembelajaran adalah proses yang 
memengaruhi mahasiswa dalam mempelajari bahasa sehingga pengertian kesalahan berbahasa dalam hal ini adalah penyimpangan yang bersifat sistematis, konsisten, dan menggambarkan kemampuan peserta didik dalam tahap tertentu (biasanya belum sempurna).(Nurjayanti, 2020)

Unsur kesalahan berbahasa yang termasuk dalam kategori linguistik adalah kesalahan fonologis (mencakup ucapan bagi bahasa lisan dan ejaan bagi bahasa tulis), kesalahan morfologis (mencakup prefiks, infiks, sufiks, konfiks, simulfiks, dan perulangan kata), kesalahan sintaksis (mencakup frasa, klausa, kalimat), dan kesalahan leksikal atau pilihan kata. Kesalahan penggunaan ejaan adalah kesalahan penulisan kata atau kesalahan menggunakan tanda baca. Kesalahan penulisan kata meliputi kesalahan penulisan kata dasar, kata turunan, bentuk ulang, gabungan kata, kata ganti, singkatan dan akronim, dan penulisan angka dan lambing bilangan. Tidak hanya itu, di dalam pedoman umum ejaan yang disempurnakan, kesalahan berbahasa tidak hanya membahas penulisan kata dan pemakaian tanda baca saja, tetapi juga pemakaian huruf kapital, huruf miring yang juga termasuk ke dalam ejaan. (Supriani \& Siregar, 2012)

Dari latar belakang yang telah dibahas di atas, dapat dituliskan rumusan masalah "Bagaimana perbandingan kesalahan berbahasa yang dilakukan mahasiswa dalam tiga mata kuliah wajib universitas yang berbeda di Universitas Esa Unggul?" dengan tujuan mengungkap kesalahan berbahasa yang terdapat dalam tugas mahasiswa Universitas Esa Unggul Semester Ganjil 2020/2021 dan mengungkap kesalahan berbahasa yang digunakan mahasiswa dalam tiga mata kuliah wajib universitas yang berbeda (Bahasa Indonesia, Pendidikan Kewarganegaraan, dan Agama Islam).

\section{METODE PENELITIAN}

Proses kerja penelitian kualitatif tidak boleh tertukar, harus berurutan secara linier. Proses kerja dimulai dari perumusan masalah, perumusan hipotesis, penyusunan instrumen, pengumpulan data, analisis data, dan penulisan laporan penelitian. Penggambaran proses analisis data dijabarkan oleh Miles dan Hubermen sebagai berikut (Rijali, 2019)

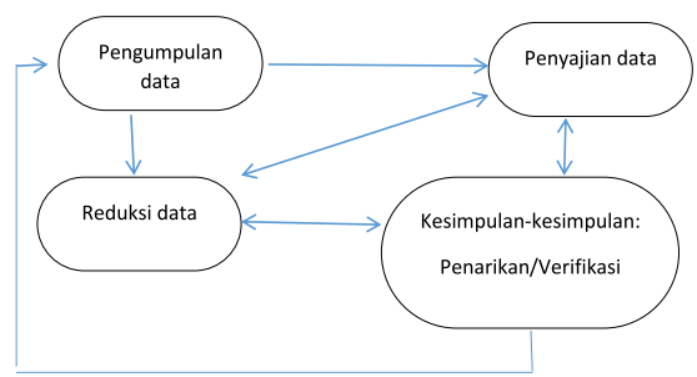

Gambar 1. Proses Analisis Data Penelitian Kualitatif

Dari gambar berikut dapat terlihat sifat interaktif pengumpulan data dengan analisis data yang merupakan bagian integral dari analisis data. Selanjutnya diikuti dengan reduksi data yang merupakan upaya penyimpulan data dengan memilah data menjadi satu konsep, kategori, dan tema tertentu untuk diolah menjadi lebih utuh guna memudahkan pemaparan dan penegasan simpulan. Adapun proses reduksi data membutuhkan interaksi "bolak-balik" tergantung pada kompleksitas permasalahan yang akan dibahas dan ketelitian peneliti dalam melakukan komparasi ketika proses pengumpulan data.

Analisis isi digunakan sebagai metode penelitian ini sebagaimana yang dijelaskan Lasswell sebagai pelopor analisis isi memperkenalkan teknik pengkodean simbol, yakni mencatat lambang atau pesan yang disusun secara sistematis lalu diberi interpretasi. Analisis isi digunakan peneliti yang ingin memperoleh penjelasan yang terkandung suatu isi komunikasi yang disampaikan dalam bentuk tanda-tanda, simbol-simbol, lambang-lambang, atau kriteria tertentu lainnya. (Arafat, 2018)

\section{HASIL DAN PEMBAHASAN}

\section{Konjungsi}

Konjungsi atau yang disebut juga dengan kata penghubung (kata sambung) dalam bahasa Indonesia berarti kata tugas, yang menghubungkan dua satuan bahasa yang sederajat: kata dengan kata, frasa dengan frasa, atau klausa dengan klausa. Kata penghubung 
didefinisikan sebagai alat yang dipakai untuk menghubungkan sebuah kalimat dengan kalimat. Adapun kata penghubung yang dimaksud meliputi kalua, meskipun, dan, kemudian, sesudah itu, di samping itu. (Yani, 2018)

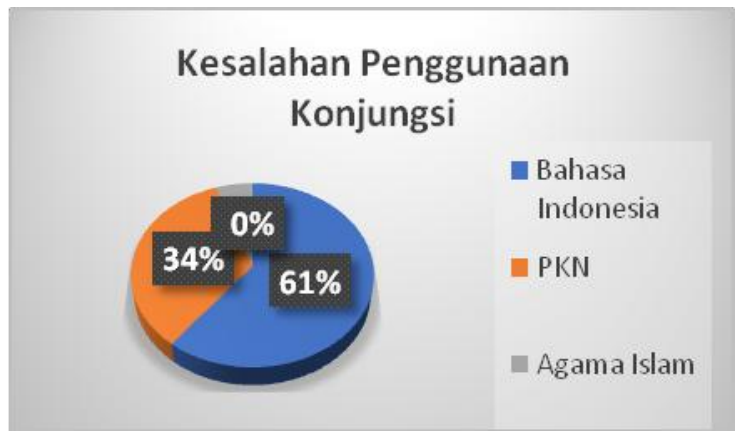

Gambar 2. Diagram Kesalahan Penggunaan Konjungsi

Dari diagram di atas dapat dilihat pemerolehan kesalahan penggunaan konjungsi di tiga mata kuliah universitas (MKU) yakni Bahasa Indonesia, PKN, Agama Islam memiliki perbedaan angka yang jelas. Kesalahan penggunaan konjungsi paling banyak pada mata kuliah Bahasa Indonesia sebesar 61\%, diikuti Pendidikan Kewarganegaraan sebesar 34\%, dan Agama Islam 5\%.

\section{Penulisan Huruf Kapital}

Huruf kapital atau huruf besar merupakan huruf yang berukuran dan berbentuk khusus (lebih besar dari huruf biasa). Dapat dikatakan penulisan huruf kapital adalah aturan yang harus ditaati oleh pemakai bahasa untuk keteraturan dan keseragaman bentuk dalam bahasa tulis yang biasanya digunakan sebagai huruf pertama dari kata pertama awal kalimat, huruf pertama unsur nama orang, huruf pertama nama geografi, dan sebagainya.(Widyawati \& Indihadi, 2018)

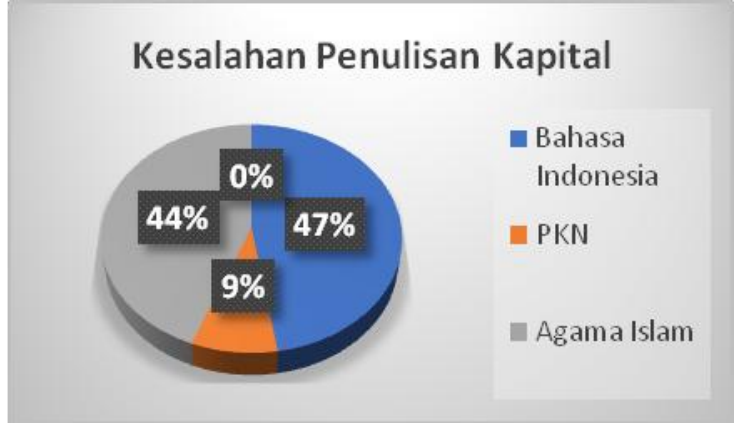

Gambar 3. Diagram Kesalahan Penulisan Huruf Kapital

Dari diagram di atas dapat dilihat pemerolehan kesalahan penulisan kapital di tiga mata kuliah universitas (MKU) yakni Bahasa Indonesia, PKN, Agama Islam memiliki perbedaan angka yang jelas. Kesalahan penggunaan konjungsi paling banyak pada mata kuliah Bahasa Indonesia sebesar 47\%, diikuti Agama Islam sebesar 44\%, dan Pendidikan Kewarganegaraan 9\%.

\section{Tanda Baca}

Pemakaian tanda baca merupakan hal penting dalam bahasa tulisan karena di dalamnya terdapat gagasan secara tertulis yang lebih sulit daripada bahasa lisan. (Enung Siti Nurjanah, Aan Kusdiana, 2014) Kesalahan ejaan menurut Sasongko bisa menimbulkan kegagalan pembaca, kegagalan disebabkan ketidakpahaman tulisan yang dilakukan oleh penulis. Ejaan merupakan lambang bunyi ujaran yang menempatkan tanda titik, tanda koma, tanda titik koma, tanda hubung, tanda seru, tanda pisah, tanda tanya, dan garis miring dalam sebuah kata. (Fitriani \& Rahmawati, 2020)

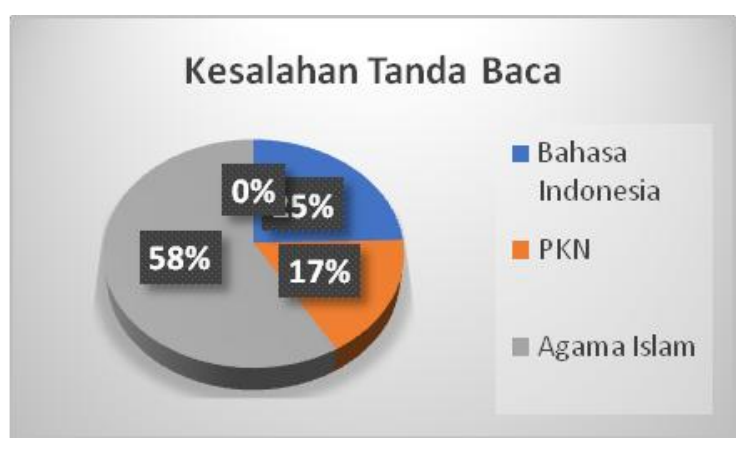

Gambar 4. Diagram Kesalahan Penulisan Tanda Baca 
Dari diagram di atas dapat dilihat pemerolehan kesalahan tanda baca di tiga mata kuliah universitas (MKU) yakni Bahasa Indonesia, PKN, Agama Islam memiliki perbedaan angka yang jelas. Kesalahan penggunaan konjungsi paling banyak pada mata kuliah Agama Islam sebesar 58\%, diikuti Bahasa Indonesia sebesar 34\%, dan Pendidikan Kewarganegaraan 17\%.

\section{Kata Baku}

Menulis dapat dikatakan baik jika sesuai dengan aturan yang berlaku seperti menulis menggunakan kata baku salah satunya. Kata baku merupakan kata yang cara penulisannya ataupun pengucapannya sesuai dengan kaidah yang telah dibakukan. Kata baku ditetapkan berdasarkan kesepakatan. (Rahmawati \& Royana, 2019)

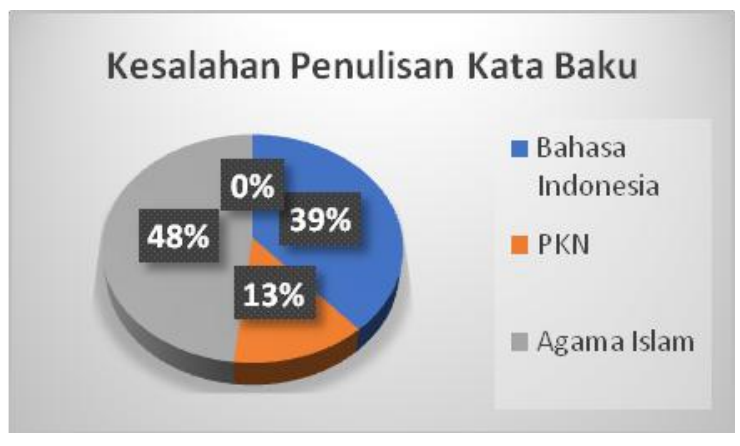

Gambar 5. Diagram Kesalahan Penulisan Kata Baku

Dari diagram di atas dapat dilihat pemerolehan kesalahan penggunaan konjungsi di tiga mata kuliah universitas (MKU) yakni Bahasa Indonesia, PKN, Agama Islam memiliki perbedaan angka yang jelas. Kesalahan penggunaan konjungsi paling banyak pada mata kuliah Agama Islam sebesar 48\%, diikuti Bahasa Indonesia sebesar 39\%, dan Pendidikan Kewarganegaraan 13\%.

\section{KESIMPULAN}

Berdasarkan hasil data yang telah dianalisis didapat simpulan: Setiap kategori kesalahan berbahasa yang dianalisis dalam penelitian ini memiliki besaran hasil yang berbeda-beda. Dalam mata kuliah Bahasa Indonesia, kesalahan berbahasa terbanyak sebesar $61 \%$ ada pada kategori kesalahan penggunaan konjungsi (kata hubung), dilanjut dengan kesalahan penulisan huruf kapital sebesar $45 \%$, kesalahan penggunaan kata baku $39 \%$, dan kesalahan penggunaan tanda baca sebesar $25 \%$.

Berbeda dengan Bahasa Indonesia, mata kuliah Pendidikan Kewarganegaraan (PKN) kesalahan terbanyak ada pada konjungsi $34 \%$, kesalahan penggunaan tanda baca $17 \%$, kesalahan pemilihan kata baku 13\%, dan kesalahan penulisan huruf kapital 9\%. Sedangkan untuk mata kuliah Agama Islam kesalahan terbanyak ada pada kesalahan penggunaan tanda baca sebesar $58 \%$, dilanjut $48 \%$ pada kesalahan penggunaan kata baku, $44 \%$ pada kesalahan penulisan huruf kapital, dan 5\% pada penggunaan kata baku.

Seluruh kesalahan berbahasa pada tiga MKU yang disebutkan di atas dijabarkan dengan diagram frekuensi berikut

\section{Diagram 6. Frekuensi Kesalahan Berbahasa pada MKU Bahasa Indonesia, PKN, dan Agama Islam}

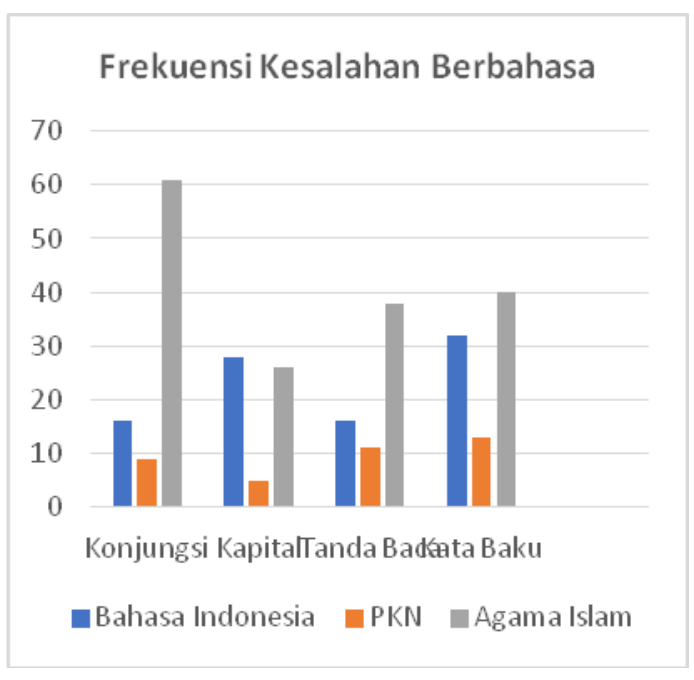

Jadi, dari pembahasan hasil penelitian dapat digambarkan ke dalam diagram di atas dengan skala frekuensi yang ada dari tiga tugas mata kuliah yang menjadi data penelitian ini.

\section{REFERENSI}

Arafat, G. (2018). Membongkar Isi Pesan dan Media dengan Content Analysis Gusti Yasser Arafat UIN Antasari Banjarmasin. 17(33), 32-48. 
Arnesti, N., \& Hamid, A. (2015). Penggunaan Media Pembelajaran Online - Offline Dan Komunikasi Interpersonal Terhadap Hasil Belajar Bahasa Inggris. Jurnal Teknologi Informasi \& Komunikasi Dalam Pendidikan, 2(1). https://doi.org/10.24114/jtikp.v2i1.3284

Enung Siti Nurjanah, Aan Kusdiana, S. A. (2014). Kesalahan Penggunaan Tanda Baca Titik Dan Koma Dalam Karangan Narasi Siswa Kelas V Di Sekolah Dasar. PEDADIDAKTIKA: Jurnal Ilmiah Pendidikan Guru Sekolah Dasar, 1(2), 20-29.

Fitriani, A. Y. R., \& Rahmawati, L. E. (2020). Analisis kesalahan penggunaan tanda baca dan huruf miring dalam teks berita online detiknews dan tribunnews. Bahastra, $\quad 40(1), \quad 10$. https://doi.org/10.26555/bahastra.v40i1.1 4695

Hartanto, W. (2016). Penggunaan E-Learning sebagai Media Pembelajaran. Jurnal Pendidikan Ekonomi, 10(1), 1-18.

Netty Fitria Dinanti, Susetyo, dan P. U. (2019). ANALISIS KESALAHAN PENGGUNAAN BAHASA INDONESIA PADA JURNAL ILMIAH PENDIDIKAN MIPA FKIP UNIVERSITAS BENGKULU. Jurnal Ilmiah Korpus, 3(2), 191-202. https://www.academia.edu/38922036/The _Integration_of_Technology_into_Englis h_Language_Teaching_The_Underlying Significance_of_LMS_in_ESL_Teaching _despite_the_Ebb_and_Flow_of_Implem entation?email_work_card=viewpaper\%250Ahttps://doi.org/10.1155/2016 /3159805\%25

Nurjayanti, P. L. (2020). Kesalahan Berbahasa dalam Lembar Karya Tulis Ilmiah Mahasiswa. https://doi.org/10.31227/osf.io/5msa2

Rahmawati, I. A., \& Royana, I. F. (2019). Analisis Kesalahan Penerapan Kata Baku Dan Tanda. 24(2), 259-269.

Rijali, A. (2019). Analisis Data Kualitatif. Alhadharah: Jurnal Ilmu Dakwah, 17(33), 81. https://doi.org/10.18592/alhadharah.v17i 33.2374

Sadikin, A., \& Hamidah, A. (2020). Pembelajaran Daring di Tengah Wabah Covid-19. Biodik, 6(2), 109-119. https://doi.org/10.22437/bio.v6i2.9759

Supriani, R., \& Siregar, I. R. (2012). Penelitian Analisis Kesalahan Berbahasa. Edukasi Kultura, 67-76.

Widyawati, K., \& Indihadi, D. (2018). PEDADIDAKTIKA : JURNAL ILMIAH PENDIDIKAN GURU SEKOLAH DASAR Penggunaan Gadget. Jurnal Ilmiah Pendidikan Guru Sekolah Dasar, 5(2), 372-379. https://ejournal.upi.edu/index.php/pedadi daktika/article/view/25731/12211

Yani, I. (2018). Analisis Kesalahan Kongjungsi Pada Karangan Deskripsi Siswa Kelas Ix Smpn 12. 3(8). 